REVISTA DE DERECHO UNED, núm. 3, 2008

\title{
DON GIL DE LAS CALZAS VERDES: MATRIMONIO Y DERECHO
}

\author{
ENRIQUE VIVÓ DE UNDABARRENA \\ Profesor Honorario de la Uned
}

Resumen: El teatro de Tirso de Molina en cuanto a la Comedia de capa y espada, se sitúa entre sus inicios con Lope de Vega y su culminación con Calderón de la Barca, superándolos por lo que a la mujer se refiere. Frente a Lope en sus enredos cómicos, las féminas tirsianas dotadas de coraje, de fuerza y de autodeterminación, llevan más libres la iniciativa. Se ha señalado que adelantándose a Calderón fue el primero en idear tramas que hiciesen del teatro un juego laberíntico que el pone a favor de la mujer, con lo que compensa su situación ante el vendaval erótico de Don Juan burlador de Sevilla, su creación universal. Adviértase que el nombre de la protagonista travestida de don Gil es precisamente el de doña Juana.

Si del mito de Don Juan se puede decir que es de carácter marcadamente atemporal, no ocurre lo mismo con Don Gil que con sus calzas verdes se sitúa en un tiempo muy concreto, que no es otro que el contemporáneo al espectáculo; lo cotidiano, coetáneo al espectador, es lo que adoba la trama y el tema, compartidos por muchos de los asistentes al corral: las rivalidades amorosas, las promesas matrimoniales engañosas que la mujer no acepta que se incumplan, el restablecimiento de su honor mancillado; y al mismo tiempo la condenación del matrimonio impuesto a los hijos por intereses económicos familiares. Con ello el fraile Mercedario se adentra en el mundo del Derecho y en la crítica de las costumbres, en la línea de la Reforma tridentina.

El recurso usado para urdir la trama y conseguir esos propósitos acordes, es curiosamente el fingimiento de la personalidad, utilizando en el caso la misma arma que el adversario. Tirso fue quien mejor 
rendimiento sacó al más clásico de los disfraces escénicos: la mujer vestida de varón, disfraz por otra parte tan fustigado por razones de moralidad sexual.

Queremos volver a insistir en la utilización que Tirso de Molina hace de los recursos jurídicos que conoce y aplica con acierto sutil.

Palabras clave: Promesa de matrimonio, Esponsales, «Matrimonio in fieri» y "matrimonio in facto esse», Intervención paterna, Imposición matrimonial, Normativa tridentina, "Dolo malo" y «dolo bueno".

Abstract: The theater of Tirso de Molina on the Comedy layer and sword lies between its beginnings with Lope de Vega and its culmination with Calderon de la Barca, overcoming as far as women are concerned. Faced with Lope in his comic entanglements, feminists tirsianas endowed with courage, strength and determination, have more free initiative. It has been pointed out that Calderon was ahead of the first to devise plots that make theater a game that puts labyrinthine in favour of women, which compensates its situation before the squall erotic Burlador de Sevilla. Please note that the name of the protagonist of transvestites Gil is precisely the gift of Juana.

If the myth of Don Juan can say is a sharply timeless, the same is not true that Don Gil with their boots are green lies in a very specific time, which is none other than the contemporary spectacle, the everyday, coeval the viewer, Adobe is what the plot and theme, shared by many of those attending the corral: rivalries love, marriage misleading promises that the woman does not accept the bypassing, restoring stained their honor, and at the same time the marriage imposed by the economic interests of the family. This Mercedario is entering the world of law and criticism of the customs, in accordance with the Tridentine Reform.

The appeal used to achieve these purposes and chords is curiously the lost of the own personality. In the specific case, it will happend using the same weapon as the adversary. Tirso perfomance's was one of the most classic of theatrical costumes: women dressed in male disguise, moreover, for reasons of sexual morality.

Summarium. I.- INTRODUCCIÓN: SIGNIFICADO Y CIRCUNSTANCIAS: a. La fecha de escritura y representación. - b. La intención o propósito de la obra.- c. Interpretación por la compañía de Pedro Valdés. II.- ACTO 1.': PRESENTACIÓN Y CONSIDERACIONES: A. LA PUESTA VISUAL EN ESCENA: a. A las puertas de Madrid: la "puente Segoviana». - b. Mujer enamorada disfrazada de varón. - c. Caramanchel, el pícaro mozo de muchos amos. - B. CONSIDERA- 
CIONES JURÍDICAS. PROMESA DE MATRIMONIO: a. Esponsales en el Derecho Romano y Cristiano. - b. En el Derecho Medieval. El "Corpus Iuris Canonici». - c. En la normativa del Concilio de Trento. - C. LA INTERVENCIÓN PATERNA EN EL MATRIMONIO: a. El consentimiento paterno en el Derecho Romano. - b. Voluntad paterna en el Derecho Canónico Medieval. - c. Intervención paterna en la legislación histórica española. - d. En el Concilio de Trento. - D. LOS HECHOS: a. Relato de dña. Juana tras los pasos de don Martín. - b. El proyecto matrimonial para don Martín. - c. La presentación del pretendiente.- d. Engaño e imposición paterna por partida doble. - e. Encuentros: Baile en la Huerta del Duque. - f. La sorpresa de don Martín. III.- ACTO 2.: LOS HECHOS QUE SE CONTRAPONEN: A. DOÑA JUANA DE URDEMALAS: a. Múltiples trazas contadas por la protagonista.- b. Dña. Juana en Valladolid y preñada. - B. EL CERCO DE DON MARTÍN: a.- Sospechas de don Martín. b.- Intentando sin éxito el inmediato casamiento. - c. Don Martín desenmascarado, rechazado y perseguido. IV.- ACTO 3. : APLICACIÓN DEL DERECHO Y DESENLACE: A. EL DERECHO: a. Promesa de matrimonio seguida de consumación. - b. Imposición paterna, Comedia y línea Tridentina. - B. HACIA EL DESENLACE: a. Don Martín supersticioso. b. Nueva patraña y celos de tres mujeres. - c. Multiplicación y confusión de los Giles. - d. El recuento de siniestros. - C. JUSTICIA FINAL: a. «La trampa se cierra». - b. La "trampa se abre». - c. Cuando baja el telón.

\section{INTRODUCION: SIGNIFICADO Y CIRCUNSTANCIAS}

Una de los objetivos de esta Comedia, es la presentación de la mujer que lejos de acobardarse, por sí misma, sin necesidad de otra ayuda, puede poner en marcha con su decisión e ingenio la restauración de su honor. Es verdad que para ello se sirve de astucias y hasta de engaños, pero según decía Don Quijote, en el noviazgo, en las contiendas amorosas, como en la guerra, caben las estrategias que lo lleven a buen puerto. ${ }^{1}$

1 CERVANTES, Quijote II, cap. 21: «Así como en la guerra es cosa lícita y acostumbrada usar de ardides y estratagemas para vencer al enemigo, así en las contiendas y competencias amorosas se tienen por buenos los embustes y marañas que se hacen para conseguir el fin que se desea». 


\section{A. LA INTENCIÓN O PROPÓSITO DE LA OBRA}

No hay que perder de vista que «aun cuando el argumento base es serio, su puesta en escena es un ballet, un divertimento que llega a ser alucinante». ${ }^{2}$ Se le ha calificado como la comedia de enredo más perfecta del Siglo de Oro. ${ }^{3}$

\section{Comedia de fondo aleccionador}

Parece constituir la lección de esta Comedia una certera crítica frente a la opresión de determinados abusos sociales, a saber: el incumplimiento de la palabra empeñada, la imposición paterna y el atropello de la autonomía y libertad de los hijos, el interés codicioso familiar, los engaños y falsificación. Pero no hay que olvidar que estas críticas son presentadas y tratadas en la perspectiva y estructura de una comedia. Sobre este fondo los reivindicadores representan esa danza en un puro ámbito teatral, donde predomina la burla.

\section{Comedia de capa y espada}

La comedia reproduce un ambiente urbano, dentro del cual tanto los decorados escénicos como los actores son los de todos los días. Personajes de aquel tiempo y lugar que visten capa y espada como los espectadores; que viven unas aventuras enredadas, con engaños, errores de identidad, enfados, persecuciones, desafíos y sucesos que reflejan el acontecer cotidiano de la vida urbana de la época. ${ }^{4}$

\section{B. FECHA DE REDACCIÓN}

Consta documentalmente que fray Gabriel Téllez, había escrito Don Gil de las Calzas Verdes en su celda de Santa Catalina de Toledo, en agosto de 1614, época de su mayor actividad dramática. ${ }^{5}$

2 LY, N. Don Gil, en "Le personnage en question», Toulouse 1984, pág. 192

3 ASENSIO J., Casos de amor en la comedia de Tirso de Molina, en Cuadernos Hispanoamericanos 289-290, 1974, pág. 69

${ }^{4}$ ARELLANO IGNACIO, Comedia de capa y espada, en «Diccionario de la Comedia del Siglo de Oro», de Castalia, Madrid 2002, pág. 53

5 SAN ROMÂN FCO. DE BORJA, Lope de Vega, los cómicos toledanos y el poeta sastre. Serie de documentos inéditos de los años 1590 a 1615. Archivo Histórico provincial de Toledo, Madrid 1935, pág. 209 
Pero antes de descubrirse la fecha, la Comedia misma le reveló a doña Blanca de los Ríos, que había sido escrita en ese año, así por el lugar en que se pone su acción como por las citas y alusiones en ella contenidas. ${ }^{6}$

\section{REPRESENTACIÓN POR LA COMPAÑÍA DE PEDRO VALDES}

Fue estrenada por el «autor», director de comedias Pedro Valdés, destacado comediante y su mujer, que interpretó con su compañía a Tirso en varias ocasiones. ${ }^{7} \mathrm{Y}$ lo fue en el pintoresco «Mesón de la Fruta» de Toledo, en julio de 1615.

Pedro Valdés estaba casado con Jerónima Burgos, actriz famosa que había sido amante de Lope de Vega. Jerónima (la señora Gerarda) tuvo el papel de la protagonista; ${ }^{8}$ pero como era corpulenta, adiposa y no muy niña, la personificación del gentilísimo don Gil de las Calzas Verdes no fue muy acertada. ${ }^{9}$

${ }^{6}$ Las escenas VI, VII, VIII, IX y X del Acto I. ${ }^{\circ}$, suceden en la "Huerta del Duque», muy de moda en 1614, en cuyo año se representó en ella La Santa Juana, de Tirso en presencia de Felipe III y de su hijo, el futuro Felipe IV. Otro dato de 1614 lo tenemos en la escena II del acto II. ${ }^{\circ}$ diciendo Caramanchel: Por una vuestra vecina que es hija de Celestina. Esta mención a la hija de Celestina es clara referencia a la novela de Salas Barbadillo La ingeniosa Elena hija de Celestina, escrita en 1612, año en que salió impresa en Zaragoza y en Lérida. Y finalmente los dos versos últimos de la comedia que aluden al incidente de la caída de las calzas, hecho ocurrido también de 1614.

7 SAN ROMÁN F., loc. cit. Pedro Valdés figuró entre los doce «autores» (directores) que entraron en la Junta de Reformación de comedias, y entre los autorizados especialmente de 1615 a 1617.

8 DE LOS RIOS BLANCA, Edición crítica de las Obras Dramáticas de Tirso de Molina, Madrid 1969, vol. I, pág. 1708. Se estrenó en el año mismo en que Lope de Vega, fue a Toledo para ordenarse de epístola y de evangelio y se hospedó en casa de la comedianta, según se lo participó al duque de Sessa: "Aquí me ha recibido y aposentado la señora Gerarda (Jerónima) con muchos cariños. "

9 TIRSO DE MOLINA, Los Cigarrales de Toledo, Cigarral cuarto, Ed. Said Armesto, Madrid 1913, pág. 340. Ello fue con gran desesperación de Tirso, que consignó claramente el fracaso por boca de uno de los personajes de El vergonzoso en Palacio, donde enumera las causas de los naufragios de las obras dramáticas: «La segunda causa de perderse una comedia es por lo mal que le entalla el papel al representante. ¿Quién ha de sufrir ver que, habiéndose su dueño desvelado en pintar una dama hermosa, muchacha y con tan gallardo talle que, vestida de hombre, persuada y enamore la más melindrosa dama de la Corte, salga a hacer esta figura una del infierno, con más carnes que un antruejo, más años que un solar de la Montaña y más arrugas que una carga de repollos, y que se enamore la otra y le diga: ¡Ay qué Don Gilito de perlas! Es un brinco, un dix: jun juguete del amor!» 


\section{ACTO 1.: PRESENTACIÓN Y CONSIDERACIONES}

El arranque de la comedia expone en un extenso parlamento entre ama y criado la información que permite conocer los antecedentes para seguir la trama de la comedia.

\section{A. LA PUESTA VISUAL EN ESCENA}

El disfraz masculino de doña Juana, aspecto esencial y que domina durante la comedia, aparece ya en el plano visual, antes de que el diálogo se inicie. El atuendo masculino de doña Juana con sus calzas verdes que da título a la comedia, «introduce el teatro dentro del teatro", ya que la mujer disfrazada es al mismo tiempo actor y personaje.

\section{a. En Madrid capital de la Nación}

Don Gil de las calzas verdes no sólo es una comedia urbana, sino capitalina. El deslumbramiento, la fascinación del Madrid cortesano, tuvo el correspondiente reflejo en el teatro. Su transformación en gran ciudad por una decisión regia en los finales del siglo XVI, produce el crecimiento rapidísimo y desbordado de la villa: la aglomeración de gentes de toda la extensa Monarquía de composición variopinta y bulliciosa, los edificios lujosos rápidamente construidos, aquel apretado complejo con toda su máquina administrativa, civil, militar y religiosa, era una llamada a la admiración.

\section{Madrid frente a Valladolid}

La comedia representa el transcurrir de la vida madrileña: Los parajes de esparcimiento como el puente de Segovia y paseos como el Prado de San Jerónimo y la Huerta del Duque abierta por el de Lerma durante su privanza, eran centros de reunión; el Alcázar y su plaza, sitio inevitable para gestiones administrativas; los tránsitos comerciales como la calle Mayor, la Puerta de Guadalajara, y el mercado en la Red de San Luis, lugares bulliciosos por su concurrencia; y las iglesias del Carmen y San Felipe con sus pórticos, mentideros donde se citaba la gente ociosa y elegante. 
Tirso de Molina, entusiasta madrileño, evoca no obstante cortesmente a Valladolid. ${ }^{10}$ Nombra sus iglesias de San Quince y la Victoria, sus paseos del Puente Grande, el Espolón y las huertas a las orillas del río; paga también su tributo a los tópicos, dedicando párrafos a la suciedad que arrastra el Esgueva, cloaca de la ciudad. ${ }^{11}$

\section{A las puertas: "la puente Segoviana"}

La primera presentación nos sitúa desde el inicio en Madrid arquetípico y conocido con su criticado río y su desproporcionado puente:

Ya que a vista de Madrid/y en su puente segoviana/ veas la humilde corrientel del enano Manzanares/ que corre, y se debe correr/ que en tal puente venga a ser/ lágrima de tantos ojos ${ }^{12}$.

\section{b. Mujer enamorada disfrazada de varón}

La representación todavía no se ha puesto en marcha; pero como antes que oírle le vemos, ya desde el primer momento intuimos el problema de doña Juana. ${ }^{13}$

Así como otros autores se detienen en los estragos producidos por el amor en ciertas mujeres, Tirso, mas psicólogo e interesado por la interioridad, se dedica a descubrir el impacto de la pasión sobre estas mujeres, como el mejor atenuante de sus faltas.

10 En 1601, Felipe III trasladó la Corte a Valladolid, durando su capitalidad hasta 1606 , por lo que la comedia es posterior a la vuelta de la Corte.

11 ALONSO ZAMORA, VICENTE, Introducción y Notas a Don Gil de las Calzas Verdes, Castalia, Madrid 1990, loc. cit. pág. 34. Esta recurrencia a determinados tópicos, cuerda muy pulsada por los escritores para Madrid, pueblan el espacio escénico; elogios o vilipendios serían seguidos por el auditorio con una regocijada complicidad.

12 Desde su construcción atribuida a Juan de Herrera, arquitecto del Escorial, caracterizó la silueta de la Villa, y fue constante referencia por su desproporción con el río. Textos análogos, más o menos escarnecedores del poco caudal del Manzanares se encuentran en Lope de Vega, Calderón, Quevedo y el propio Tirso.

${ }^{13}$ Las primeras ordenanzas sobre el teatro que datan de 1608 , prohíben que las mujeres vistan de varón, disponiendo que no salga ninguna mujer a bailar ni a representar en vestido de hombre, prohibición que se repite en 1615 y posteriormente, lo que muestra que no se cumplía. Observemos que la fecha en que se reitera la prohibición es al año siguiente de la puesta en escena de nuestra comedia. 
A las asechanzas y asedios del amor, siguen la perturbación de los sentidos y los desasosiegos en la mujer que se enamora:

Dos meses ha que pasó;/ un Adonis bello vi./ Diome un vuelco el corazón./ Entré en casa enajenada./ No dormí, no sosegué;/ levánteme con ojeras, / desojada, por abrir/ un balcón, de donde luego/ mi adorado ingrato vi./ Dio en servirme:/ papeles leí de día,/ músicas de noche oí,/ joyas recibí.

\section{c. Caramanchel el pícaro, mozo de muchos amos}

El encuentro con Caramanchel, que entra de mozo de don Gil de las Calzas Verdes, ha tenido lugar junto al Puente de Segovia, a la puerta de un bodegón.

Su presentación es respuesta de Caramanchel en lenguaje de pícaro, al saludo del de Las Calzas Verdes:

-¡Hola! ¿Qué es eso?

- Oye hidalgo/: A las doce sólo digas/ "Olla, olla» y no "hola, hola»

Caramanchel no desempeña otra función que la de provocar la risa, y ser testigo asombrado de las transformaciones de su amoama que no alcanza a controlar.

Caramanchel en su presentación pasa revista a una galería crítica de los múltiples amos a que ha servido, con las acostumbradas figuras en el género picaresco.

\section{B. CONSIDERACIONES JURÍDICAS: PROMESA DE MATRIMONIO}

Sin olvidar su sentido de enseñar divirtiendo, vamos a detenernos en el trasfondo que pone de relieve costumbres contrarias a Derecho que el autor fustiga.

\section{a. Prenotandos}

1. Matrimonio «in fieri» $y$ matrimonio "in facto esse»

Al entrar en el tema matrimonial previamente hay que advertir que la comedia no se interesa por el matrimonio como estado con- 
yugal y situación social; con lenguaje del Derecho diríamos que su atención no enfoca al matrimonio «in facto esse», sino al llamado por la Doctrina «matrimonio in fieri» o celebración matrimonial.

Una vez desaparecida la posibilidad del matrimonio presunto, las peripecias, se ponen en el noviazgo, acostumbrado pórtico amoroso y en la decisión de contraer matrimonio; estos momentos claves del proyecto y celebración matrimonial inciden en la comedia, como más aptos para el ámbito dramático provocando su trayectoria laberíntica.

\section{Mujer y matrimonio en la comedia}

El desenlace en boda se hace lugar común en la comedia, conclusión convencional que refleja la concepción de la sociedad del Siglo de Oro, según la cual la mujer ha de cumplir con su destino de casarse y de ser madre. Se ha observado que la mujer casada no es personaje de comedia, a no ser que el tema sea el de un marido celoso.

Las mujeres, en el desarrollo de la trama dentro del género cómico tienen peculiar actuación, manipulando el desenlace y alterándolo; y aunque éste siempre concluya con la restauración del orden social y haya que casarse para cumplir con los convencionalismos, la protagonista mientras tanto conduce la acción y se divierte a expensas de los varones que han intentado perjudicarla. ${ }^{14}$

\section{Paradigmas de la evolución de las costumbres}

Las leyes son el reflejo de las costumbres seculares de un pueblo, y las reformas legislativas nos muestran la evolución que se ha producido en dichas costumbres; unas veces por una transformación paulatina en la sociedad y otras por el predominio de principios distintos que van abriéndose camino en la vida social y que terminan por imponerse en su ordenamiento. Lo contemplamos en dos temas, que pueden muy bien servir de paradigma: los esponsales o promesa de matrimonio y la intervención paterna en la elección del mismo, temas abordados por Tirso en esta Comedia. Barca.

14 El ejemplo clásico de este tratamiento es «La dama duende» de Calderón de la 


\section{b. Los esponsales en el Derecho romano y cristiano}

Los esponsales fueron práctica de los pueblos antiguos como los hebreos, griegos y romanos, contratados a veces muchos años antes del matrimonio. La definición que nos ofrece el Derecho Romano recoge lo que en esencia se puede decir de esta institución:

\section{Esponsales son palabra y promesa mutua de matrimonio ${ }^{15}$.}

Recibidos del Derecho Romano, serían reforzados en el Cristianismo por influencia de los esponsales judíos de efectos más decisivos.

La entrega de un anillo a la novia, vieja tradición pagana, fue conservada entre los cristianos como lo muestran los textos primitivos. ${ }^{16}$

La Iglesia sin hacer de los esponsales un paso obligado para el matrimonio como tampoco lo habían sido en el Derecho Romano, preocupada por el respeto a la palabra dada, apremiaba a quienes se prometían el matrimonio, sancionando con penas su ruptura sin justa causa. ${ }^{17}$ Sin embargo parece que desde antiguo en el fuero eclesiástico las censuras encaminadas al cumplimiento de la promesa matrimonial no se aplicaban siempre. ${ }^{18}$

15 D. 1, 23, 1,2,3. Como explica Ulpiano se llaman esponsales, de «spondeo», me comprometo. Es la joven la que es prometida por esposa, pues el esposo no es objeto de promesa ("sponsus non promittitur»); así aparece en el teatro de Plauto y Terencio.

D. $23,1,4$. Su normativa era ya escueta: Basta el solo consentimiento para constituir esponsales.

D. 3, 2, 1 in fine, y 13,1 al 4. Entre sus efectos se señala la prohibición bajo pena de infamia de concertar nuevos esponsales o contraer matrimonio con otra persona, sin antes haber roto el primer compromiso.

D. $45,1,134$. Paulo recuerda que una cláusula que previese una indemnización en caso de que los esponsales no concluyesen en el matrimonio proyectado, era considerada nula pues desde antiguo se quería que el matrimonio fuese libre.

16 TERTULIANO, Apologeticus adversus gentes, 6, 4, M. L. 1, 302. Es en el Occidente cristiano el primer testimonio de la costumbre de los esponsales, cuando critica la degradación romana y dice que en otro tiempo ninguna mujer conocía más oro que el del único anillo que el esposo le habia puesto en el dedo en prenda de matrimonio.

17 Concilio de Elvira, canon 54, TEJADA, Cánones y Concilios de la Iglesia Española, Madrid 1850. vol. I, pág. 82. La norma de que los esponsales no se pueden romper sin causa alcanzan también a los padres de los futuros esposos. Así el Concilio de Elvira los castigaba también a ellos: Si los padres faltasen a la promesa esponsalicia, absténganse de la comunión por tres años.

18 CHELODI J., El Derecho Matrimonial, Barcelona 1959, pág. 40. 


\section{c. En Derecho Medieval. El «Corpus Iuris Canonici»}

Para algún autor los esponsales llegaron a ser ignorados y fueron retomados de los textos romanos redescubiertos en los siglos XII y XIII. ${ }^{19}$ Sin embargo Nicolás I hacia el año 867 no sólo nos define los esponsales en términos precisos, diciendo que son promesa de futuras nupcias, sino que nos los presenta como práctica ordinaria previa al matrimonio de los fieles en Occidente. ${ }^{20}$

El historiador Esmein insiste en la gran importancia que los esponsales tuvieron en el Feudalismo, siendo el medio de pactar alianzas entre dos familias y estando destinados a establecer o asegurar la paz entre ellas. ${ }^{21}$

Ninguna forma era exigida para la valida celebración de los esponsales aunque en la emisión de esta promesa a veces jurada, solían darse las arras y la entrega del anillo a la prometida. ${ }^{22}$

La edad requerida para la validez de los esponsales no parece haber sido fijada por el Derecho durante largo tiempo. Graciano, recoge la referencia a la facultad de dar el consentimiento que los rige. ${ }^{23}$

El Derecho Canónico en defensa de la libertad del matrimonio, lo mismo que algunos ordenamientos civiles, hizo pronto patente su tendencia a no forzar la celebración del matrimonio pactado en los esponsales; así consideraba su obligación no como absoluta sino disyuntiva: o el matrimonio, o el resarcimiento de daños.

19 GAUDEMET JEAN, El matrimonio en Occidente, Madrid 1993,. pág. 431.

20 NICOLÁS I, Responsa ad consulta Bulgarorum, XCVII, 3, Migne Latino, vol. 119 , col. 979

21 ESMEIN GENESTAL, Le Mariage en Droit Canonique, París 1929, pág. 164. Las leyes más marcadas por la tradición romana, conservaban los esponsales; así la «Lex Romana Visigothorum» con su versión del «Fuero Juzgo», y la «Lex Romana Burgundiorum» que recoge todavía las arras de esponsales del Derecho Romano tardío.

${ }^{22}$ La bendición de los novios en los esponsales sólo aparece en Occidente hacia el siglo XIII. A menudo los esponsales eran acompañados de juramento o fidei datio. Convertido en forma habitual del contrato de esponsales, le han dado el nombre en algunas lenguas románicas, tomándolo del verbo latino «affidare»; en francés «fiancer», en italiano "fidanzare»(prometida=»fidanzata»).

${ }^{23}$ GRACIANO, Decretum, Cau. XXX, q. 2, dictum ante c. únic. Los esponsales no se pueden contraer antes de los siete años. Sólo se contrae mediante el consentimiento, lo cual no se produce si ambas partes no entienden qué es lo que hacen. Se prueba por tanto que los esponsales no puede ser contraidos por niños cuya tierna edad no admite el consentimiento. 


\section{En el Decreto de Graciano}

La normativa que rige los esponsales no se halla totalmente especificada en el Derecho Canónico antiguo:

Inocencio III deja claro que los esponsales de futuro se disuelven por un matrimonio posterior consumado y no por otros esponsales aunque sean jurados. ${ }^{24}$

Pero los esponsales jurados de futuro ciertamente se disuelven por el acuerdo de las partes. La doctrina nos ofrece los distintos modos de su disolución. ${ }^{25}$

Alejandro III todavía sostiene con imposición de censuras canónicas la obligación de contraer de quien lo prometió con juramento. ${ }^{26}$ Pero hay autores que se refieren a la excomunión sólo en el caso de ser ambos desposados mayores e intervenir juramentos. ${ }^{27}$

\section{En las Decretales, Liber Extra de Gregorio IX}

La disciplina que desaconseja la coacción de las censuras manteniéndose sólo la monición canónica, la encontramos decididamente ya en el Papa Lucio III, sucesor inmediato de Alejandro III. ${ }^{28}$ Grego-

${ }^{24}$ Liber Extra, IV, tit. I, c. 22, Inocencio III en la Decretal «Sicut ex literis tuae fraternitatis"

${ }^{25}$ GOFREDO DE TRANO, Summa perutilis super libros Decretalium, Ventiis, 1502, fol. 68 final: «El primero es el disentimiento del desposado cuando llega a edad de consentir; el segundo cuando uno de los esposos ha marchado a otra región y esperado durante largo tiempo no vuelve; el tercero si un de los esposos contrae la lepra u otra enfermedad enorme; el cuarto cuando los esposos mutuamente se liberan; el quinto si sobreviene afinidad por la fornicación de alguno; el sexto cuando uno de los esposos cae en la herejía que es como adulterio; el séptimo si uno de los desposados contrae por palabras de presente con tercera persona; el octavo si uno entra en religión pues se disuelven los esponsales de presente. Pero en estos dos últimos casos se disuelven los esponsales en Derecho por el mismo hecho; en los otros casos mediante sentencia».

${ }^{26}$ Extra, IV, tit. I, c. 10, Alejandro III en la Decretal "Ex literis Silvani»: Si amonestado legítimamente se negase a obedecer tu decisión, le impondrás pena de excomunión y prohibirás celebrar en todo su territorio funciones sagradas, excepto el bautismo de párvulos y la confesión de los moribundos.

27 TANCREDO, Summa, tit. 5, pág. 7 s. «Si ambos son mayores e intervinieron juramentos se les ha de obligar con la excomunión a consumar el matrimonio. Pero si no intervino juramento se les ha de amonestar a que lo consuman y no se les ha de obligar porque las nupcias contra voluntad suelen tener malos resultados".

28 Extra, IV, tit. I, c. 17, Lucio III en la Decretal «Requisivit a nobis»: Te respondemos brevemente, que a la mujer que juró que se casaría, como el matrimonio deba ser en 
rio IX propugnará la liberación de toda coacción en los esponsales; ${ }^{29}$ actitud que observamos también en algunos Concilios Provinciales. ${ }^{30}$

Para Santo Tomás en virtud de la promesa esponsalicia, los interesados se obligaban mutuamente a contraer matrimonio, pecando gravemente el que incumple la promesa, siempre que no intervenga una causa legítima. La Iglesia imponía una penitencia por el pecado; mas en el fuero contencioso negó la acción para obligar a contraer. ${ }^{31}$

\section{En El Fuero Juzgo y en Las Partidas,}

El Fuero Juzgo impone dura sanción a quien quebranta la obligación de los esponsales, situación que aborda particularmente en caso de negativa de la desposada. ${ }^{32}$

El Rey Sabio al expresarse en Las Partidas sobre la obligación que conllevan los esponsales, se extiende en torno a los distintos modos de celebrarlos. ${ }^{33}$

derecho libre, se le ha de amonestar más que obligar, sobre todo porque tales coacciones suelen tener frecuentemente resultados duros.

${ }^{29}$ Extra, IV, tit. I, c. 29, Gregorio IX en un caso en que se quería hacer cumplir una pena pecuniaria acordada en los esponsales para el que se negase a contraer, manda que se prohíba al interesado exigir tal pena, dando la razón: Como los matrimonios deben ser libres, tal estipulación en la que se establece una pena ha de ser rechazada.

${ }^{30}$ Así el Sínodo de Trier de 1310 determinó esta penalización bien suave: A las prometidas que rota la fidelidad de los esponsales contraen con otros, no se les dé la bendición nupcial. Con ello se les equiparaba a las viudas.

31 STO. TOMÁS, In Senten. IV, D. XXVII, q. 2, a. 1. «En el fuero contencioso (fuero externo), no se le obliga al renuente sin causa a contraer, a no ser que hubiese intervenido juramento».

32 Fuero Juzgo, edic. Real Academia, Madrid 1815, lib. III, tit. I, ley 2, pág.46. Si alguno desposa la manceba de voluntad de su padre, e la manceba contra voluntad de su padre quisiere casar con otro, e non con aquel a quien la prometió su padre, aquesto non lo sofrimos por nenguna manera que ella lo pueda fazer. Onde si él la osare tomar por mugier, ambos sean metidos en poder daquel con que la desposaran de la voluntad de su padre. E todavía la voluntad daquellos non sea firme, e ambos sean dados assí cuemo es dicho de suso con todas sus cosas en poder de aquel que la avie ante desposado.

${ }_{33}$ ALFONSO X, Partidas, IV, tit. 1, leyes 1, 3, 8, 10. Desposorios se fazen: La que demuestra el tiempo qes por venir, se puede fazer en cinco maneras: La primera es como si dixesse el ome ala muger: yo prometo que te recibire por mi muger; e ella dixesse: yo te recibire por mi marido. La segunda es quando dize: fago te pleyto casarme contigo; e la muger dize a el esso mesmo. La tercera es quando juran el uno al otro, que se casará en uno, como si dixesse: yo juro sobre estos evangelios o sobre esta cruz, o sobre otra cosa, que casare contigo. La quarta es si le da alguna cosa, diziendo assi: yo te do estas arras, e prometo que casare contigo. La quinta es cuando le mete algun anillo en el dedo, diciendo asi: yo te do este anillo en señal que casare contigo.

$Y$ sobre su obligación: Ca los que prometen que casaran uno con otro, tenudos son de cumplir, fueras ende si alguno dellos pusiesse ante si excusacion alguna derecha. 


\section{d. El silencio del Concilio de Trento}

En el Derecho canónico nunca se había establecido una solemnidad para el valor de los esponsales, a pesar de los daños que sobrevenían por los esponsales clandestinos, que hasta el Tridentino se convertían si accedía la cópula en matrimonio presunto.

Advertimos que en esta Comedia de Tirso de Molina no hace al caso el tema del matrimonio presunto, tan socorrido en la Literatura, porque la acción de la misma se sitúa en tiempos en que tal modo de celebración matrimonial no es válido. ${ }^{34}$

Nada estableció tampoco dicho Concilio sobre el modo de celebrar los esponsales, a pesar de la instancia de algunos obispos; los Romanos Pontífices constantemente habían manifestado que nada se debía innovar, prohibiendo que se diesen en los Sínodos nuevas normas regulando los esponsales. Favorecer la plena libertad del matrimonio, era el objetivo procurado ya en el antiguo Derecho canónico de las Decretales, llegándose a negar la acción para obtener el cumplimiento de la promesa u obligación proveniente de los esponsales.

\section{LA INTERVENCIÓN PATERNA EN EL MATRIMONIO}

Es otro ejemplo de la interacción entre las costumbres y las leyes, cuya trayectoria resulta muy interesante por la abusiva interposición de la voluntad paterna, viéndose así afectada la libertad de los contrayentes.

\section{a. En el Derecho Romano}

La intervención de los padres en el matrimonio, medida de protección sobre todo de las hijas, fue objeto en varias Constituciones del Bajo Imperio.

${ }^{34}$ La consideración de la promesa de matrimonio como matrimonio presunto cuando se ha seguido la consumación, depende de la época y tiempo en que se haya querido colocar la acción de la comedia. Así es claro que en El Burlador de Sevilla que se sitúa en el siglo XIV cabe tal tipo de matrimonio; no ocurre lo mismo en Don Gil de las Calzas Verdes, que transcurre contemporáneamente en el siglo XvII, por lo que no se tratará de un matrimonio presunto sino de promesa incumplida con un engaño o defraudación en razón de una entrega adelantada. 


\section{Libertad para el matrimonio}

Un famoso texto representaba el principio de la libertad matrimonial como algo consagrado: Desde antiguo se quiso que fueren libres los matrimonios ${ }^{35}$.

Hay que tener presente que el matrimonio romano no era como el actual una relación determinada por un consentimiento inicial, sino por un consentimiento continuado, de forma que se extinguía por la voluntad contraria; la libertad debía continuar en todo momento.

\section{Consentimiento del paterfamilias en el matrimonio}

La norma romana requería el consentimiento del padre tanto en el caso del esposo como de la esposa, cuando los futuros esposos estaban todavía bajo su potestad; faltando el consentimiento del paterfamilias, no habrá iustae nuptiae y los hijos que naciesen no serían legítimos.

La necesidad del consentimiento de los padres hacía que la voluntad sin más de los contrayentes filiifamilias, no tuviese suficiente valor. ${ }^{36}$

\section{Sobre matrimonio impuesto por el padre}

Textos contrarios han dado lugar a la duda.

Así Celso en un pasaje se pone la invalidez del matrimonio contraído patre cogente, en relación con la imposibilidad de contraer inter invitos. ${ }^{37}$

$\mathrm{Y}$ en cambio un fragmento de Terencio Clemente declara su validez. ${ }^{38}$

${ }^{35}$ C. Ius. 8, 39, 2. Constitución del emperador Severo. Cfr. DI MARZO SALVATORE, Lezioni sul Matrimonio romano, Roma 1972, pág. 5.

${ }^{36}$ D. 23, 2, 2, Paulo: No pueden existir las nupcias sino consienten todos, a saber, los que contraen y aquellos bajo cuya potestad están.

37 D. 23, 2, 22 Si coaccionándole su padre toma una esposa con la que no se hubiese casado de su voluntad, contrae matrimonio a pesar de ello; se considera que prefirió contraerlo a oponerse a su padre. milia.

${ }_{38}$ D. $23,2,21$ : No cabe la coacción para que contraiga matrimonio un hijo de fa- 
4. Collocare filiam in matrimonio

Se ha planteado la cuestión del matrimonio de la hija de familia en la interpretación de la curiosa expresión collocare filiam in matrimonio, que aparece en diversos textos. ${ }^{39}$

Para algún autor significaría el poder paterno de unir en matrimonio a su hija, prescindiendo de su voluntad y aun en contra de la misma. No hay duda de que semejante interpretación se opone a muchos textos, en los que se afirma sin distinción alguna, la absoluta necesidad del consentimiento de los cónyuges para el matrimonio. La hija que se ha casado habría dado un asentimiento al menos formal. ${ }^{40}$ Parece que la expresión collocare filiam in matrimonio, es coloquial y sólo significaría que el padre da su consentimiento en el matrimonio de la hija. ${ }^{41}$

\section{El matrimonio contraído sin el consentimiento paterno}

Paulo afirma ciertamente que sin el consentimiento paterno hay matrimonio, pero no siendo conforme a Derecho no se pueden constituir en consecuencia iustae nuptiae. ${ }^{42}$

A diferencia del consentimiento de los esposos, el de los paterfamilias manifestación de la patria potestas, es sólo un requisito. ${ }^{43} \mathrm{La}$ diversidad es esencial: el uno constituye la affectio maritalis causa del matrimonio y el otro en cambio es exigido para el matrimonio, pero

39 D. 23, 2, 38, Paulo en un texto famoso: No se prohibe que el que ejerce alguna función en una provincia pueda casar en ella a sus hijas ("filias suas in matrimonium collocare»). Esta misma expresión la vemos en Juliano, Marciano, Gaio, Ulpiano.

40 ORESTANO R. La struttura del matrimonio romano I, pág. 363, en «Bulletino dell Istituto di Diritto Romano", Milano 1952. Parece haber demostrado que el Derecho Romano admitía la validez del matrimonio impuesto por el padre, porque no considera que esta imposición sea exclusoria del consentimiento de la hija.

41 GAUDEMET, Iustum matrimonium, en "Etudes de droit Romain», III, Università di Camerino 1979, pág. 319

42 Paulo, Sentent. 2, 19, 2: Sin la voluntad del padre, aquellos bajo cuya potestad están, no pueden en Derecho contraer matrimonio; pero éste no se disuelve una vez que se ha contraído. En Ulpiano, Epítome, 5, 2, encontramos idéntica prescripción: Hay justas nupcias si consienten ambos si son «sui iuris", y también los padres de ellos si están bajo su potestad.

${ }^{43}$ Las afirmaciones de los Juristas respecto a la necesidad del consentimiento paterno concuerdan en que es una exigencia del orden jurídico romano para que el hijo nacido de un tal matrimonio pueda ser iustus filius. 
no especificativo del instituto. ${ }^{44}$ Por ello puede en ciertas circunstancias no darse.

Podrá faltar el consentimiento del paterfamilias por enajenación y por ausencia e ignorancia de su paradero; ${ }^{45} \mathrm{e}$ incluso por su negativa, pudiendo ser suplido y aun no ser suplido, porque es accesorio. ${ }^{46} \mathrm{Y}$ otro tanto ocurría en caso de cautividad. ${ }^{47}$ Con Augusto comienza a atenuarse el consentimiento del paterfamilias. ${ }^{48}$

\section{La disolución por el paterfamilias}

El consentimiento de los patresfamilias debía perdurar durante la convivencia del matrimonio, de modo que éstos podrían romper la relación haciendo uso de su potestad..$^{49}$

Las Constituciones imperiales del siglo II y III d. C. pondrán remedio, impidiendo al padre el separar a la hija si ésta no lo consiente, dejando en tal caso de producirse la disolución por voluntad del paterfamilias. ${ }^{50}$

44 Esta diferencia salta a la vista, por el hecho de que el consentimiento paterno no es requerido sino respecto de los hijos que son alieni iuris. Y es claro que su matrimonio no puede consistir en algo diverso del matrimonio de los que son sui iuris, porque no son matrimonios esencialmente distintos.

45 D. 23, 2, 10, Paulo: Cuando el padre está ausente y se ignora su existencia y paradero, al cabo de tres años, no se prohíbe que sus descendientes de ambos sexos contraigan matrimonio conforme a la ley.

${ }_{46}$ ROBLEDA OLIS, El matrimonio en Derecho Romano, Roma 1970, pág. 161. En el caso de locura del paterfamilias o de su ausencia, tanto los hijos como las hijas tenían que esperar tres años antes de contraer matrimonio, pero si lo hacían antes, el matrimonio era válido, con tal de que apareciese cierto que el paterfamilias lo habría de tener por bueno.

47 D. 23, 2, 9, 1, Ulpiano: Aquel cuyo padre ha caído en las manos de los enemigos si no vuelve dentro de un trienio puede casarse.

48 DI MARZO S. loc. cit. pág. 47. En la «Lex Iulia de maritandis ordinibus» del año 18 a.C. se permite al Pretor prescindir del consentimiento del paterfamilias, si éste se niega a darlo sin motivo. Puede ser suplido por el Magistrado y aun dispensado. Facultad semejante es reconocida también por el derecho Justinianeo.

49 ASTOLFI RICCARDO, Il matrimonio nel diritto romano preclassico, Verona 2000 , pág. 92. Se recurría para ello a la ductio, o manus iniectio privada con la que el padre separa a su hija del marido, aun contra su voluntad y la reintegra a la casa paterna. Si el matrimonio se había acompañado de la conventio in manu, el padre había perdido la potestad sobre la hija, en cuyo caso no podía recurrir a la ductio para interrumpir el matrimonio. En la época Preclásica los matrimonios son normalmente cum manu, por lo que el uso de la ductio en aquella época es raro. En la época Clásica es utilizada todavía aunque con carácter excepcional pues la frecuencia de los matrimonios sine manu aumenta desde el siglo III a C.

50 D. 24, 1, 32, 19; D. 43, 30, 1, 5; Paulo, Sentent. 5, 6, 15, dice que Antonino Pío prohibió que un matrimonio bien acordado fuese separado por el padre. Y en Sentent. 
Los emperadores Diocleciano y Maximiano se refieren a esta prohibición. ${ }^{51}$

\section{b. En el Derecho Canónico Medieval}

Siguiendo los principios del Derecho Romano, se considera indubitable que el consentimiento de los contrayentes es causa del matrimonio.

\section{No puede ser dado en matrimonio sin su voluntad}

Una Decretal del Papa Hormisdas (514-523), afirma que un padre no puede casar a su hijo sin que acceda el consentimiento de éste. ${ }^{52}$

Se trata de un texto que se atribuye a un Papa de la antigüedad, lo que supone como un principio de siempre la necesidad del consentimiento del hijo a quien el padre quiere casar. ${ }^{53}$

\section{El solo consentimiento de los esposos es suficiente}

Nicolás I, en la "Respuesta» a los Búlgaros del año 866, completa la consulta que se le hacía cerca de los ritos nupciales, diciendo significativamente del consentimiento:

Es suficiente según las leyes, el sólo consentimiento de aquellos de cuya unión se trata. Si falta él sólo en las nupcias, todo lo demás realizado aun el mismo coito, no tiene valor. ${ }^{54}$

$2,19,2$, da la razón diciendo que no se disuelve, porque se prefiere tener en cuenta la utilidad pública que las conveniencias privadas.

51 C. Ius. 5, 17, 5

52 GRACIANO Decreto, Cau. XXXI, q. 2, c. 2 y Liber Extra, tit. II, c. 1 en un texto calificado de incierto por Friederberg, que se introdujo como una "palea" en el Decreto de Graciano, y se repite en el «Liber Extra».

${ }_{53}$ HORMISDAS I, Decreta, III, M. L. 63, 526: Vuestra piedad nos preguntó venerable hermano, sobre un hijo adulto que su padre quiere casar, si lo puede hacer sin la voluntad de dicho hijo adulto. A lo cual respondemos, que si de algún modo no consiente el hijo, que no lo puede hacer.

54 NICOLÁS I, Responsa ad consulta Bulgarorum, III, M. L. vol. 119, col. 980. Al centrar todo su valor en el consentimiento, el Papa Nicolás I abre la larga polémica medieval sobre la causa eficiente del matrimonio, en la cual se produce un desplazamiento de los términos de discusión, que dejan de ser el consentimiento o la bendición, para pasar a ser los del consentimiento o la cópula. 
3. El peligro del uxoricidio en los matrimonios impuestos

La doctrina y la jurisprudencia ofrecían también la objeción del peligro en que se coloca la vida del cónyuge en el caso de las bodas no queridas y odiadas.

Sto. Tomás señala el uxoricidio entre los malos resultados que suelen tener los matrimonios coaccionados. ${ }^{55}$

\section{c. En la legislación histórica española}

La necesidad para el menor de obtener la licencia paterna para contraer matrimonio, es principio común de los distintos Ordenamientos.

Entre los antecedentes españoles, además del Fuero Juzgo, ${ }^{56}$ es digno de especial mención por lo categórico de sus prescripciones el Fuero Viejo de Castilla. ${ }^{57}$

Y en el mismo sentido el Fuero Real, ${ }^{58}$ y Las Partidas. $^{59}$

\section{d. En el Concilio de Trento}

La exigencia del consentimiento paterno para la validez del matrimonio de los hijos de familia, fue anatematizada en el Decreto «Tametsi».

${ }^{55}$ STO. TOMÁs, In Senten. IV, D. XXVII, q. 2, a. 1

${ }^{56}$ Fuero Juzgo, lib. III, tit. 1, ley 8

57 Fuero Viejo de Castilla,(edic. Madrid 1771) lib. V, tit. 5, ley 1: Si alguna manceba en cabellos sin voluntad de suos parientes los propinquos e de sus cercanos coermanos casare con algund ome e se ayuntase con el por cualquier ayuntamiento, que non aya parte en lo de su padre, ni en lo de la madre, e sea enagenada de todo eredamiento.

${ }_{58}$ ALFONSO X, Fuero Real,(edic. Real Academia de la Historia, Madrid 1836) lib. III, tit. 1, ley 5 y 6: Si la manceba en cabello casare sin consentimiento de su padre e de su madre, non parta con sus hermanos en la buena del padre ni de la madre, fuera ende si el padre o la madre la perdonaren.

59 ALFONSO X, Partidas, IV, tit. 3, ley 5: El matrimonio se haga a paladinas e con sabiduría del padre e de la madre de aquella con quien quisier casar, si los hobiese; si non de los otros parientes más cercanos. 


\section{Validez del matrimonio sin consentimiento paterno}

La cuestión fue planteada al Concilio en una propuesta de los Obispos franceses; la nobleza gala a la que pertenecían en su mayoría, pretendía que el consentimiento paterno era condición esencial del matrimonio de los hijos de familia. ${ }^{60}$

Por su parte Lutero inspirado en el antiguo Derecho Germánico, requería para la validez el consentimiento paterno cuando uno al menos de los futuros cónyuges estaba aún sometido a la autoridad de sus padres. ${ }^{61}$

\section{Se condena el exigir la autorización para la validez}

El Decreto «Tametsi» lejos de prescribir la autorización paterna para la validez del matrimonio de los hijos de familia, condena a quienes sostienen que hacerlo sin tal autorización era contraer inválidamente. ${ }^{62}$

Reprobación muy clara con la que respondía de algún modo, a los requerimientos tanto de los Obispos franceses como de los embajadores del Rey de Francia. ${ }^{63}$

El Decreto sin embargo mantenía la prohibición del matrimonio sin autorización paterna. ${ }^{64}$

Se ha observado que al oponerse los Padres de Trento a la necesidad de la aprobación paterna para la validez del matrimonio de los

${ }^{60}$ Los embajadores del Rey Carlos IX de Francia trataron de presionar a los Padres del Concilio para que se declarase nulo el matrimonio de los hijos de familia sin autorización de sus padres. También el Rey de Portugal había hecho la misma petición al Pontífice.

${ }^{61}$ En el Interim de la Dieta de Ausburgo (1548) el emperador Carlos V determinó que era obligación moral tener ese consentimiento, pero que no era una condición para la validez de la unión matrimonial.

${ }_{62}$ Concilio Tridentino, Ses. XXIV. Decreto «Tametsi»: También se condena con anatema a los que equivocadamente afirman, que los matrimonios contraídos por los hijos de familia sin consentimiento de sus padres son irritos y que los padres pueden hacerlos ratos o irritos.

${ }^{63}$ NAZ R. Dictionaire du Droit Canonique, pág. 736: A pesar de ello la legislación civil francesa a través de medios indirectos exigió la necesidad de tal consentimiento, como se manifesta en una declaración de 26 de noviembre de 1639 y en un Edicto de marzo de 1697.

${ }^{64}$ Concilio Tridentino, Ses. XXIV. Decreto "Tametsi»: No obstante la Santa Iglesia de Dios, por las más justas razones, siempre ha detestado y prohibido semejantes uniones. 
hijos de familia, que contaba con potentes y numerosos propugnadores, se reivindicaba el principio básico del ius connubii, reafirmando al mismo tiempo la autonomía del consentimiento de los cónyuges como causa eficiente del matrimonio.

\section{LOS HECHOS}

\section{a. Relata Dña Juana los pasos de don Martín}

Desde el principio se plantea la razón de toda la Comedia en su causa motiva:

En dos meses don Martín/ de Guzmán, que asi se llamal dióme palabra de esposo,/ tan pródiga en las promesas/ como avara en el cumplir.

\section{La lista de los atropellos del galán}

En el relato de don Gil de las Calzas verdes se enumera: la infidelidad y el engaño a una mujer dejándola deshonrada, aceptación de otro matrimonio impuesto por manipulación paterna por interés económico, y huida y suplantación tratando de burlar la Justicia mediante nombre falso.

Ofrecióse un casamiento/ de una doña Inés, con setenta mil ducados./ Escribió su viejo padrel al padre de don Martín/ pidiéndole para yerno/ No se atrevió a dar el síl claramente, por saber/ que era forzoso salir mi deshonra./ Previno postas el viejo/ e hizo a mi esposo partir./ Díjole que se mudasel el nombre de don Martín/ con el nombre de don Gil,/ por si de parte mía/ viniese en su busca aquí/ la Justicia.

2. Sobre la obligación perseguible por la Justicia

La promesa de matrimonio obteniendo el favor sexual, produce ciertamente una obligación que podía ser perseguida por la Justicia. Que se trata de promesa seguida de cópula, se deduce sin más de la referencia a que un nuevo matrimonio pondría forzosamente al descubierto que la prometida quedaba no sólo engañada sino también deshonrada. Para evitarlo y entorpecer la acción de la Justicia su padre le hace marchar a Madrid simulando que es otra persona con el nombre falso de don Gil de Albornoz Doña Juana ha reaccionado va- 
lientemente, poniéndose en marcha tras el fugitivo para estorbar la otra boda y recuperar a su galán. Y lo va a hacer con toda clase de armas.

Saqué fuerzas de flaqueza, / disfraceme como ves./ Yo, pues que he de ser estorbo/ malogrando cuanto hiciere.

\section{b. El proyecto matrimonial para don Martín}

Se plantea ya aunque de paso, el otro tema de fondo de la comedia, el de la libertad de matrimonio de los jóvenes enamorados, frente a los intereses pecuniarios de sus padres viejos ambiciosos.

Don Andrés, padre de don Martín impone el matrimonio a su hijo con doña Inés, rica heredera, haciéndole abandonar a su prometida doña Juana, y otro tanto intenta don Pedro, padre de doña Inés desechando a don Juan pretendiente de ésta. Don Gil de las Calzas Verdes completa así el relato de los hechos:

Escribió luego a don Pedro/ padre de mi opositora,/ dándole a sentir el pesar/ de que impidiese la liviandad juvenil/ de su hijo el concluirse/ casamiento tan feliz;/ que por estar desposado/ con doña Juana Solis/ enviaba en su lugar/ a un don Gil.

La actuación del padre de don Martín dando cuenta de que su hijo está "desposado" con doña Juana Solís se envilece aún más, porque diciendo que le envía otro candidato para la boda con doña Inés, hace a su hijo simular ser esa distinta persona; suplantación para burlar la posible acción que se teme de la Justicia.

Quedan así esbozados los dos temas de fondo: La promesa de matrimonio que se trata de soslayar con la huida de don Martín bajo el nombre supuesto de don Gil de Albornoz, y al mismo tiempo la intromisión de los dos padres imponiéndose a la elección amorosa de sus hijos por la codicia de juntar dos mayorazgos.

\section{c. El antagonista se presenta}

En escena la casa de don Pedro, padre de doña Inés, al que vemos leyendo la carta de recomendación que le ha traído don Martín el pretendiente, que simula ser otro galán distinto. 


\section{La carta de recomendación}

La misiva firmada por don Andrés, padre de don Martín, es un doble fraude afirmando presentarle para la boda con doña Inés, en vez de a su hijo don Martín, a un noble gentil "don Gil de Albornoz» a quien recomienda, pero a quien suplanta el mismo don Martín.

(Don Pedro lee) «Digo, en conclusión, que don Martín, ha dado palabra a una dama desta ciudad, noble y hermosa, pero pobre. Y ya que mi suerte estorba tal ventura, tenedla a no pequeña, que el señor don Gil de Albornoz, que ésta lleva, esté en estado de casarse y deseoso de que sea con vuestra hija. Su mayorazgo, que heredará brevemente es de diez mil ducados de renta. La merced que le hiciéredes recibiré en lugar de don Martín. Valladolid y julio, etc. don Andrés de Guzmán.»

\section{Bajo nombre falso}

Don Pedro, padre de doña Inés, a la vista de la inviabilidad del matrimonio que él proyectaba, da satisfecho su asentimiento:

- Pues don Martín inadvertido/ hace imposible el dicho casamientol que vos en su lugar hayáis venido,/ señor don Gill me tiene muy contento.

Don Martín, resulta un sujeto sin personalidad y además sin escrúpulos pues no sólo quebranta su compromiso matrimonial por plegarse a la codicia de su padre, sino que simula impertérrito ser otra persona.

\section{d. Engaño e imposición paterna por partida doble}

La presencia del engaño en diversos planos, conforma este laberinto de enredos: Madrid a la que se le llama Babel, es el ámbito adecuado. Don Martín es el principal burlador; don Andrés mueve los hilos desde Valladolid, incitando a su hijo al abandono de Juana y a una suplantación de personalidad. Don Pedro atropella codicioso los planes matrimoniales de su hija, pues el supuesto don Gil es de mayor rango nobiliario que su prometido don Juan.

Pero el suplantador confundido por la agudeza de don Gil de las Calzas Verdes, se verá atrapado en la red que el ingenio de la dama va a tender para su captura. 


\section{El objetivo doloso de unir dos mayorazgos}

Las bodas entre mayorazgos iban poniendo en unas pocas manos la riqueza del país. Las Cortes de 1527 ya levantaron su voz en contra de tal costumbre. ${ }^{65}$

Los dos viejos urden objetivos codiciosos ilegítimos (dolo malo), a diferencia de doña Juana que se sirve del ardiz para defenderse (dolo bueno), y restaurar su derecho atropellado.

La actuación paterna interesada por partida doble, busca doble efecto: no solo quebrantar la promesa de matrimonio de don Martín a doña Juana, sino también contrariar los amores de doña Inés con don Juan su prometido, a quien tiene también dada palabra de matrimonio. Promesa de matrimonio que repite Doña Inés a don Juan, cuando éste se muestra preocupado y celoso:

Don Juan,/ Tú solamente has de ser/ mi esposo.

\section{Doña Inés hija perjudicada que se rebela}

Don Pedro que ha escuchado sorprendido y contrariado esta declaración de su hija doña Inés, le recrimina luego, por no haber obtenido previamente su beneplácito, dándole entonces cuenta del matrimonio que ha concertado con don Gil de Albornoz; la joven se rebela contra tal boda acordada sin ella saberlo y sin ni siquiera haber conocido antes al pretendiente. Se reitera el tema del casamiento impuesto, y la imagen del codicioso don Pedro, que desatiende el compromiso de su hija.

- Esposo tienes mejor/ Aqui ha venido/ un bizarro caballero/ rico de Valladolid./ Diez mil ducados de renta hereda.

65 ALONSO DE SANTA CRUZ, Crónica del Emperador Carlos V, II,387, citado por Américo Castro, "Lo hispánico y el erasmismo», en Revista de Filología Hispánica, II, 1940, pág. 29.

FERNÁNDEZ DE NAVARRETE, Conservación de monarquias, Madrid, 1626, discurso XI, De los mayorazgos cortos, p. 75: «Hacían (los procuradores) saber a S. M. cómo muchos grandes de estos reinos casaban a sus hijos con otros grandes de los mismos reinos, y de dos casas se hacía una sola; de donde venía daño al reino, porque muchos caballeros e hijosdalgo, y escuderos y doncellas, y otras personas que se criaban en una de las dichas casas, no se podían sustentar, ni tenían quien les hiciese mercedes. Suplicaban a S. M. lo mandase remediar». 
$-i$ Es bien que mi gusto impidas,/ entrando amor por los ojos,/ dueño me ofrezcas de oidas?

\section{e. En la Huerta del Duque}

\section{Encuentro entre álamos y fuentes}

Un nuevo escenario, los álamos y las fuentes de la Huerta del Duque, pone en contacto a los distintos personajes: don Juan y doña Inés, su prima doña Clara, y doña Juana (don Gil de las Calzas Verdes) acompañada de Caramanchel; al son de melodías y cantares que entonan los músicos en la escena.

Alamicos del Prado/fuentes del Duque,/despertad a mi niña/porque me escuche

$Y$ pues vuestros arroyos/ saltan y bullen,/despertad a mi niña/ porque me escuche.

\section{Un paseo cortesano de Madrid}

Se hallaba la Huerta del Duque en el Prado Nuevo o Prado de Recoletos, junto a la famosa Huerta de Juan Fernández. Se llamaba así por su fundador y dueño el Duque de Medina de Rioseco y Almirante de Castilla, don Juan Gaspar Enríquez de Cabrera,. ${ }^{66}$

Para Dña. Blanca de los Ríos la concurrencia de madrileños a la "Huerta del Duque» se refiere a los días en que aquella estuvo tan de moda, como lo estuvo después la Huerta de Juan Fernández, eternizada también por Tirso. ${ }^{67}$

${ }^{66}$ Cfr. MESONERO ROMANOS, El antiguo Madrid, Madrid 1925, pág. 107. Se llama hoy por esta razón calle del Almirante la abierta en la antigua Huerta, entre Barquillo y Recoletos. Con frecuencia, se confunden la Huerta del Duque de nuestro texto con la Huerta del Duque de Lerma, situada en el Prado Viejo, desde la salida de la Carrera de San Jerónimo a la de las Huertas. Parece que la que pudo ser disfrutada públicamente fue la del Almirante, vecina a la de Juan Fernández o Huerta del Corregidor. La mayor parte de la posesión fue cedida por sus dueños para la fundación del convento de San Pascual.

${ }_{67}$ DE LOS RIOS B, loc. cit. 1707. Para la insigne crítica tirsiana, ello es una prueba de que la comedia es anterior, desde luego, a la caída de Lerma en 1618, y pertenece a la época del apogeo de aquel vergel cortesano. Tirso recuerda la Huerta en Marta la piadosa. 


\section{Empieza a tejerse la trampa amorosa}

Don Gil de las Calzas Verdes consigue enamorar a doña Inés que rechaza a don Martín, enamoramiento que despierta los celos de don Juan su bizarro pretendiente.

La escena se desarrolla al compás de la música y la danza. Significativamente don Juan, galán un tanto rudo, rehúsa bailar, mientras que don Gil lo hace elegantemente con las damas, contrastando su delicadeza (al fin mujer) con los bruscos modales del celoso don Juan. Los músicos cantan coplas del cancionero tradicional.

"Al molino del amor/ alegre la niña vala moler sus esperanzas,/quiera Dios que vuelva en paz./ Los bueyes de las sospechas/ el rio agotando van;/ y viendo que a falta de agua /parado el molino está,/ desta suerte le preguntal la niña que empieza a amar:/

-»Molinico ¿por qué no mueles?»/-»Porque me beben el agua los bueyes». ${ }^{68}$

\section{f. La sorpresa de don Martín}

\section{Dos galanes con el mismo nombre}

Introducida la confusión, doña Inés cree que el don Gil de Albornoz al que su padre le destina, es el de las calzas verdes que ha conocido en el jardín.

Se producen equívocos cómicos entre don Pedro, doña Inés y don Martín: doña Inés acepta con entusiasmo a don Gil el verde; el viejo y el pretendiente, engañados por el nombre idéntico, muestran su contento provocando el consiguiente alboroto y rechazo de doña Inés ante este otro don Gil tan distinto.

\section{Doña Clara otra enamorada celosa}

Una intriga secundaria: doña Clara, prima de doña Inés también se enamora de don Gil de las Calzas Verdes. Clara celosa tiene prisa por casarse con él, antes de que su prima se lo arrebate:

68 PENEDO MIGUEL, El fraile músico de los Cigarrales de Toledo, Estudios III, 1947, pág. 383, ha dicho de esta bellísima canción «Al molino del amor» que es la cumbre literaria de las viejas canciones de molino, abundantísimas y aun vivas en muchas partes. 
Yo en yendo a casal procuraré que mi padrel me case con él.

Acaba el acto con don Pedro y don Martín desorientados, don Juan furioso, las dos primas Inés y Clara enamoradas de don Gil de las Calzas Verdes y celosas.

\section{ACTO 2. ${ }^{\circ}$ : LOS HECHOS QUE SE CONTRAPONEN}

En este acto los enredos se multiplican. Doña Juana que aparece siempre encarnando a otro personaje, diríamos que tiene en este Acto más todavía carta de actor; la sucesión de papeles con cambio de personalidades es constante, lo que contribuye a producir un enmarañado nudo.

\section{A. DOÑA JUANA DE URDEMALAS}

No sé a quien te comparar:/ Pedro de Urdemalas eres.

Pedro de Urdemalas personaje enredador famoso, de quien andaban entre el vulgo cuentos de sus muchas tretas y burlas, es el modelo de Doña Juana. ${ }^{69}$

\section{a. Las múltiples trazas urdidas}

La misma protagonista nos cuenta las múltiples tramas que tiene en marcha:

Doña Inés pierde el sentido/ por mí. Don Martín anda buscando/ este don Gil competidor;/ desatinado entiende / que soy duende./ Pierde el viejo la paciencial porque la tal doña Inés, / ni sus ruegos obedecel ni a don Martín apetece./ Un don Juan que la servía,/ loco de ver su desdén,/para matarme me busca./ Una doña Clara que es/ prima de mi doña Inés / también me quiere, de modo/ que a su padre ha persuadido/ que me la dé por mujer.

69 ALONSO ZAMORA V. loc. cit. pág. 163: Cervantes revivió este personaje en la comedia que lleva ese nombre. Hay otros muchos Pedros de Urdemalas en el teatro, en Lope de Vega, Montalbán etc., personaje que ya utilizó Juan del Encina. El nombre de Pedro de Urdemalas y sus hechos estaban a mediados del siglo XVI en la conciencia colectiva de los españoles; Correa lo constata en varios refranes. 
Ahora va a montar una nueva estrategia, alquilando la casa contigua a la de doña Inés, introduciendo a doña Elvira personaje que es ella misma con atuendo femenino. La nueva inquilina se presenta y traba amistad con doña Inés su vecina, lo que le permitirá espiar a don Martín.

\section{b. Doña Juana en Valladolid, y preñada}

El enredo avanza con un decisivo paso en su estructuración acelerada: hace llegar a don Martín la noticia de que doña Juana ha quedado en Valladolid en el convento de San Quirce, muy quejosa de su abandono porque se halla embarazada. Con ello trata de desviar la sospecha de hallarse en Madrid en su seguimiento. Alecciona al mensajero Quintana:

$Y$ darásle muchas quejas/ de mi parte, y que si sabel mi padre de mi preñez, / me ha de dar muerte.

Nos muestra al mismo tiempo que su padre como otros de su tiempo, considera la deshonra de la mujer como una mancha familiar que se lava dándole muerte.

\section{B. DON MARTÍN ACORRALADO}

Don Gil de las Calzas Verdes que ha despertado los celos de don Juan el enamorado de doña Inés, ha conseguido de rebote que ésta haga ver a su antiguo pretendiente, que quien compite con él, no es el de las calzas verdes, sino el otro, don Gil de Albornoz, nombre que oculta a don Martín con quien se ha dispuesto su boda.

El que de casa te ha echado les un don Gil muy barbado/ a quien aborrezco yo./ Pero quiéreme casar/ con él mi padre. Si a matar/ estotro don Gil te atreves...

\section{a. Sospechas de don Martín}

\section{El mensajero convence al intrigado don Martín}

Visita Quintana con su esperpéntico mensaje a don Martín al cual, llega a convencer de que doña Juana se halla en Valladolid en el convento de San Quirce aguardando el parto; la supuesta preñez cre- 
ída sin más por don Martín, nos asegura que en la relación de ambos ha habido algo más que promesas de matrimonio. Cuando Quintana le recrimina el que no vaya a sacarla de allí, don Martín promete que irá en breve.

\section{Celos de don Juan}

Don Martín se encuentra con don Juan el pretendiente de doña Inés que encendido en celos, le desafía el cual le responde flemáticamente, poniéndose de relieve el contraste de los dos:

Don Juan caracterizado por su rudeza, es descrito irónicamente como un valentón: amenaza, desafía, saca la espada. Don Martín rehúsa la riña con razones propias de un desahogado vividor. Pero ambos son juguete de la mayor inteligencia de doña Juana.

\section{Mala conciencia de don Martín}

Una vez más se manifiesta la pobre personalidad de don Martín voluble y sin convencimientos, que persiste y busca justificación para su mala conducta.

Si está doña Inés resuelta/ y a ser mi esposa se allana,/ perdonará doña Juana,/ y mi amor dará la vuelta; que el interés/ y beldad de doña Inés/ excusan la culpa mía.

\section{b. Intentando sin éxito un pronto casamiento}

\section{Preocupación del padre de don Martín}

Don Martín lee una carta de su padre que le trae su criado:

«Hijo: Cuidadoso estaré hasta saber el fin de nuestra pretensión. Para que lo consigáis os remito esta libranza de mil escudos. Doña Juana de Solís falta de su casa desde el día que os partisteis, temiendo no os haya seguido e impida lo que tan bien nos está. Abreviad lances, y en desposándoos, avisadme para que yo al punto me ponga en camino, y tengan fin estas marañas."

Don Martín arguye frente a las noticias de Osorio el mensajero de su padre: 
Agora llegó Quintana/ con carta suya, y por ella/ he sabido que encerradal está en San Quirce y preñada./ Huyóse sin avisar a su padre.

\section{Persistiendo en su mal propósito}

Pero don Martín con el apoyo de su padre, está muy lejos de cumplir su palabra de matrimonio a doña Juana, la que según sospecha el criado, dará a luz sin matrimonio:

-Parirá en fe de doncella.

-Pero entretendrela agoral escribiéndola, y después/ que posea a doña Inés, / le diré que tome estado/ de religiosa.

Los desposorios de don Gil de Albornoz con doña Inés, urgidos por su padre se planean inmediatos. ligro.

- No hay para qué dilatarl el desposorio, que es cosal que corre pe-

- Pues esta noche estoy resuelto/ en desposarme.

3. Carta y libranza, perdidas y halladas

¡Extrañas casualidades de la comedia! La carta junto con la libranza de dineros que don Martín ha recibido de su padre, las pierde; y precisamente las viene a encontrar doña Juana, para cuyos enredos son precioso instrumento.

(Dichosa soy en extremo/ que a mi mano hayan venido estas cartas)/ y una libranza de hasta mil escudos./ Hoy cobrará la libranza/ Quintana.

\section{c. Desenmascarado, rechazado y perseguido}

1. Doña Inés desenmascara a don Martín ante su padre

La hija con la declaración de su nueva vecina, trata de convencer a su padre de la impostura de don Gil de Albornoz, al mismo tiempo que le confiesa su enamoramiento de don Gil de las Calzas Verdes.

Digo, señor, que vives engañado,/ y que el don Gil fingido que me ofreces,/ no es don Gil./Con una doña Elvira desposado,/ la misma me ha contado/ que en su busca viene./ Repara en que don Gil, el verdade- 
ro,/ es un gallardo y joven caballero/ que por la gracia vestido,/ calzas verdes le di por apellido.

\section{Don Gil de las Calzas Verdes saca de dudas a don Pedro}

El padre de doña Inés no acaba de comprender el enredo de Giles que su hija le descubre hasta que se hace presente don Gil de las Calzas Verdes, asegurándole con las cartas encontradas, que convencen al viejo.

-Conoced, señor don Gill a mi padre que os desea, ly persuadirle a que no creal enredos de un pecho vil.

-Cartas que hoy he recibido/ de don Andrés de Guzmán, / quimeras desharán.

\section{Denuestos de don Pedro al pretendiente}

Don Martín es recibido por don Pedro con calificativos de traidor y falsario, que asombran al desconcertado galán; y lo que es más, escucha confundido la conminación que le hace su prometida doña Inés para que cumpla con doña Elvira. Tal denuncia hace imposible su engañosa pretensión de contraer con doña Inés.

\section{La persecución del alma en pena de doña Juana}

Don Martín empieza a padecer alucinaciones persecutorias, creencia que sube de punto al anunciarle su criado que las libranzas incluidas en la carta perdida, han sido cobradas por el mismo don Gil de las Calzas Verdes. Las exclamaciones supersticiosas de don Martín le muestran especialmente ridículo en sus temores:

¿Hay confusión semejante? /;Que este don Gil me persiga/ invisible cada instante!/ Ninguno me hará creer/ sino que se disfrazó, / para obligarme a perder,/ algún demonio y me hurtól las cartas.

\section{ACTO 3. : APLICACIÓN DEL DERECHO Y DESENLACE}

El último acto lleva al desenlace que se ha ido gestando desde el acto anterior. En él se produce la total desorientación causada por los equívocos, que culminan con la aparición en tumulto de múltiples 
disfrazados con calzas verdes y el chocar de sus espadas con que quieren resolver las cuestiones. Ponen la nota cómica las alucinaciones supersticiosas de don Martín, hábilmente provocadas por doña Juana.

\section{A. APLICACIÓN DEL DERECHO}

El desenlace restaura el derecho dando a cada uno lo suyo, que en el caso será la celebración de unos matrimonios prometidos, realmente queridos y libres de toda imposición paterna.

\section{a. Promesa de matrimonio seguida de consumación}

Parece de sobra probado que a la promesa de matrimonio de don Martín había accedido la unión sexual, relación que si ya no produce el matrimonio presunto como ocurría antes del Decreto "Tametsi» del Concilio Tridentino, no hay duda que crea una obligación de cumplimiento como contrato en el que ha habido un anticipo, fuertemente gravoso para la mujer. La promesa del varón habría obtenido la entrega anticipada amorosa íntima, en el convencimiento de que el matrimonio se seguiría pronto. El incumplimiento es ciertamente perseguible por la Justicia. Es cierto que en el Ordenamiento canónico no se daba ya acción para reclamar en juicio la celebración del matrimonio, pero sí para exigir en disyuntiva la reparación de los perjuicios causados.

\section{b. Imposición paterna.}

\section{Comedia y línea Tridentina}

Un argumento muchas veces abordado en el teatro Aureo, gira alrededor del derecho de intervención paterna respecto al matrimonio de los hijos y particularmente de las hijas. El tema tiene un papel en las comedias que se desarrollan en torno a las relaciones amorosas y se hace presente en las intrigas del galanteo para conseguir el objetivo final de la boda.

Conforme a las costumbres imperantes en la época, la mujer es propiedad de su padre hasta casarse. La comedia saca partido de los conflictos que surgen de la oposición entre la voluntad del padre, representación de la sociedad, y el deseo de la mujer exponente de los 
derechos del individuo. Aunque el amor representado por jóvenes, generalmente suele salir triunfador frente al interés puramente crematístico representado por los padres imponiéndose la juventud a la vejez, otras veces en cambio la mujer sobre todo termina sometiéndose al imperativo social. ${ }^{70}$

\section{Principio canónico enfrentado a la praxis civil}

La Iglesia reacciona contra el sometimiento de las hijas. La doctrina canónica proclama el principio de que a partir del uso de razón no puede ser desposada (prometida) contra su voluntad, y que cuando sus padres la hayan desposado sin consultarla, ésta podrá en su momento rehusar el ejecutar esta promesa.

El debate sobre el consentimiento de los padres era un viejo asunto que enfrentaba la praxis eclesiástica con los usos civiles. Pero esta liberación de la hija se abre paso en la sociedad lentamente y con dificultad. En todos los medios y ambientes sociales rara vez en el concierto matrimonial estaban ausentes los padres, interviniendo siempre en el caso de las hijas, y también a menudo en el de los hijos.

\section{Reflejando la norma del Concilio Tridentino}

Para la Iglesia lo esencial en definitiva era la voluntad de los contrayentes. Es indudable que el teatro de nuestro Siglo de Oro, adelantado como propuesta de vida, refleja en esta época la norma progresista que se impone en la Reforma del Concilio de Trento. ${ }^{71}$

En el Decreto "Tametsi» del Concilio de Trento, se rechazó y condenó la doctrina que requería en el caso de los hijos de familia la autorización paterna para la validez del matrimonio. ${ }^{72}$

Y aunque ciertamente el Decreto "Tametsi" también reconocía que la Iglesia siempre había detestado las uniones clandestinas y a espaldas de los padres, Trento contribuyó notablemente al desarrollo de

70 VIVÓ DE UNDABARRENA E. Matrimonio y Derecho en el Teatro del Siglo de Oro: Cervantes y Calderón de la Barca, UNED, Madrid 2003, pág. 93

${ }^{71}$ MÁRQUEZ VILLANUEVA FRANCISCO, Personajes y temas del Quijote, Madrid 1975, pág. 70. Es interesante observar que en ello se opone al Protestantismo e incluso a la doctrina de algunos humanistas como Vives y Erasmo quienes propugnaban la autoridad paterna en el matrimonio de los hijos.

72 Concilio de Trento, Decreto Tametsi, Ses. XXIV 
la autonomía y de los derechos de la persona, impidiendo la consolidación de la tiranía familiar en lo referente a las nupcias de los hijos, fenómeno que había dominado durante siglos la sociedad; se superaba así la influencia del Derecho Germánico y aun la del Derecho Romano donde pesaba tanto la autoridad del paterfamilias.

\section{B. HACIA EL DESENLACE}

\section{a. Don Martín supersticioso}

El fantasma llamado don Gil de las Calzas Verdes obnubilará la imaginación del supersticioso don Martín hasta el desenlace.

\section{La fábula del fallecimiento de doña Juana}

Quintana relata a don Martín la inventada muerte de doña Juana, quedando éste convicto de ser él su causa.

Déjame contarte el cómo/ sucedió su muerte en suma:/ Llegué con tu carta,/ salió a una red doña Juana,/ dijela que en breves días/ en su presencia estarías./ Leyó tu carta tres veces./ Dijéronla que venía/ su padre y que pretendial dar venganza a su honor./ Y como estaba preñadal fue el susto tan repentino/ que a malparir al fin vino/ una niña mal formada/ y ella al dar el primer grito,/ murió como un pajarito.

\section{Don Martín perseguido por el ánima de doña Juana}

Nuevas sospechas acaban por convencer a la credulidad del galán que su perseguidor es el alma en pena de su traicionada prometida. A los quiméricos sucesos inventados por el ingenio de doña Juana se añade ahora el acoso de un fantasma. Resultan cómicas sus supersticiosas deducciones avaladas por nuevas patrañas.

No es posible, sino que es/ el espíritu inocente de doña Juana,/ que se finge don Gil./ El nunca llegarle a ver,/ el llamarse de mi nombre,/ ¿no es todo esto conjetural de que es su alma que procural que la vengue y que me asombre? 
3. Don Martín obstinado en su empeño

A pesar de ello don Martín encuentra razones para proseguir pretendiendo a doña Inés, que sin embargo le rechaza. Sus desmedidos propósitos siguiendo el mandato de su padre, pueden más que sus temores supersticiosos.

- Pero, ¿piensaste casar/ con doña Inés?

- Si murió doña Juana, y me mandó/ mi avaro padre intentar/ este triste casamiento,/ no concluirle sería/ de algún modo afrenta mía.

\section{b. Nueva patraña y celos de tres mujeres}

Tres breves escenas son otros tantos nuevos enredos que embarullan más la trama.

\section{Doña Juana supuestamente apuñalada por don Martín}

Doña Juana revela a Quintana su acompañante un sorprendente nuevo engaño: ha escrito a su padre diciéndole que apuñalada por don Martín se halla moribunda en Alcorcón.

\section{Don Gil cortejando a doña Clara}

Doña Inés sorprende indignada a don Gil de las Calzas Verdes con doña Clara su prima.

- Señor don Gil, justo fuera,/ que para mi hubiera un día.

- Desde el día que en la huertal os vi, hermosa doña Clara,/ ni tuve mañana claral ni noche segura y cierta.

- Don Gil, que os amo os confieso;/ dadme esa mano.

- De esposo os la doy; tomad.

3. Doña Inés celosa de doña Clara y doña Elvira

A doña Inés, Caramanchel que trae una carta para doña Elvira el doble femenino de don Gil, la convence de que éste tiene trato amoroso con su nueva vecina. Y ésta creyéndose doblemente pospuesta a 
Elvira y a Clara, irrumpe furiosa; y para detener sus gritos, don Gil le declara que no es lo que aparenta sino que es doña Elvira. Para demostrarlo se viste traje femenino, provocando en el final de la escena el escándalo y turbación de Caramanchel que ahora ve a su amo convertido en mujer.

\section{c. Multiplicación y confusión de los Giles}

Es de noche. A la calle de doña Inés empiezan a acudir personajes que juntos protagonizarán los episodios más cómicos.

\section{Desafio de dos varones que fingen ser don Gil}

Comienza la escena con la entrada de don Juan el valentón, embozado haciéndose pasar por don Gil de las Calzas Verdes, situándose ante la reja de doña Inés.

Acude luego don Martín vestido de verde a cortejar a la misma dama; topa con don Juan que furioso de celos le desafía. Don Martín, rechaza la lucha y se dirige al barbudo don Juan con emotivos lamentos, creyendo que es el ánima de doña Juana.

- Sacad el acero, pues.

- Yo nunca saco el acero/ para ofender los difuntos./ Doña Juana, ¿qué buscáis?/ Si por dicha en pena andáis,/ misas digo por libraros.

- ¿Qué es esto? ¿Yo doña Juana? / ¿Yo difunto? ¿Yo alma en pena?

- Alma inocente,/si por estorbar mi amor/ cuerpo aparente tomaste,l alma, cese tu porfía, que no entendí yo que habial en el otro mundo celos.

\section{Dos mujeres disfrazadas de don Gil}

Llega después doña Clara hasta la ventana de doña Inés disfrazada de varón, vestida de verde, fingiéndose don Gil.

Y culmina la confusión de los Giles, bajando a la calle la propia doña Juana que ha dejado la reja donde estaba asomada vestida de mujer y aparece ahora disfrazada de varón con sus calzas verdes.

La concentración estalla en un batirse los cuatro, siendo herido don Juan, lo que provoca la dispersión. Se escucha la voz del pícaro el único no disfrazado: 
-Lleno de don Giles voy./Cuatro han rondado esta reja; el alma enamorada/ que por suyo me alquiló,/ del purgatorio sacó/ en su ayuda esta gilada./ iQue he sido lacayo de un alma en pena!

\section{d. El recuento de los infortunios}

Todos las trampas que doña Juana ha tendido en torno a don Martín (noticias que dan cuenta de su falsa muerte, carta acusatoria de asesinato, historias de engaños y falsas identidades, representación y disfraz de don Gil) convergen en un torrente de siniestros para el galán, que lo sumerge en un desastre total.

\section{Lamentaciones de don Martín en el Prado}

En el Prado de San Jerónimo, el lugar de esparcimiento preferido de la Corte, ${ }^{73}$ don Martín recuenta en un monologo sus desventuras;

A doña Inés adoro. ¿Esto merecel que don Gil mis deseos desvanece?/Si a doña Inés pretendo, un don Gil luego/ pretende a doña Inés y me la quita./ Si me escriben, don Gil me usurpa el pliego./ Si dineros me libran, cuando llego/ hallo que este don Gil cobró la dita.

Tirso lo resumen en un refrán, Nunca nos ha de faltar un Gil que nos persiga, que acomoda a la circunstancia, sin que pierda su frescura. ${ }^{74}$

2. Entre la realidad madrileña y la esperpéntica

En Don Gil son constantes las apelaciones a Madrid como Babel o golfo de vicios y de trampas de gente vividora.

73 El Prado de San Jerónimo ocupaba el sitio del actual Paseo del Prado, cuyo embellecimiento definitivo se debe a Carlos III, ya en el siglo XVIII. Su nombre le venía del monasterio de Jerónimos fundado en tiempo de Enrique IV, y del que persisten iglesia y claustro. El Prado es lugar de entrevistas amorosas, desafíos, etc., en toda la literatura clásica. Tirso de Molina, lo pone en escena también en La villana de Vallecas. Para la historia del famoso paseo, véase Mesonero Romanos.

${ }^{74}$ COVARRUBIAS, Tesoro de la lengua castellana s. v. Gil: El verso reproduce el refrán que da explicación a la comedia. Se había convertido en proverbio un verso castellano de un soneto, dando a entender que aunque desista un émulo, no falta otro que le sustituya en su lugar. 
La encarnación de la obra en Madrid, se hace ahora con referencia a las Casas a la malicia lo que se llamó regalía de aposento. ${ }^{75}$

- -Calles de aquesta Corte,/ casas a la malicia, a todas horas/ de malicias y vicios habitadas!/ ¿Quién a los cielos en mi daño instiga / que nunca falta un Gil que me persiga?

Don Martín considera Madrid como el paradigma de su situación.

\section{JUSTICIA FINAL}

Entramos en el última secuencia escénica que se estructura en dos miembros, dentro de un esquema general de contraste y movimiento alternativo.

\section{a. "La trampa se cierra»}

Don Diego padre de doña Juana ha llegado a Madrid, traído por la falsa noticia del intento de asesinato de su hija.

\section{Don Martín detenido}

Las desgracias de don Martín llegan a su extremo cuando a instancia de don Diego, un alguacil lo detiene por el imaginado asesinato de aquella en Alcorcón. Aunque realmente sea una farsa, es ocasión para que se denuncie algo ciertamente real, como el haber usurpado una personalidad que no es la suya.

- Éste es el don Gil fingido/ a quien conoce su patrial por don Martín de Guzmán,/ y el que ha muerto a doña Juanal

- Llegad, y prendedle.

75 Construidas con una sola planta de cara a la calle para eludir la obligación del «derecho de aposento» (obligación de ceder habitaciones para el servicio de los funcionarios reales). Felipe II ordenó que se reservase al gobierno el segundo piso de cada edificio que se construía, a fin de destinarlo a vivienda de funcionarios, cortesanos, etc. De ahí que la gente, para esquivar la disposición regia, procurase construir casas sin apariencia de varios pisos. 


\section{Don Martín se defiende}

Don Martín argumenta contra la falsa acusación del crimen con razones concluyentes de su inocencia, lo cual no obsta para que reconozca haber abandonado a su prometida, a la que cree haber dejado embarazada.

- De esposo le di palabra;/ partime luego a esta Corte,/ dicen que quedó preñada./ Si de malparir una hijal se murió estando encerradal en San Quirce, ¿tengo yo/ culpa desto?

\section{b. La «trampa se abre»}

\section{Para desenredar el embrollo}

El padre de doña Juana venido de Valladolid, comprueba que ésta vive y que su doble muerte ha sido sólo un ardiz para hacer cumplir su promesa de matrimonio a don Martín y a su padre. Así lo confiesa doña Juana para dar satisfacción de sus marañas.

- Todo fue porque vinieses / a esta Corte donde estabal don Martín hecho don Gil / y ser esposo intentaba/ de doña Inés.

\section{Don Martín sale de la trampa dando su mano de esposo}

El diálogo de doña Juana (don Gil de las Calzas Verdes) con don Martín lleva finalmente al triunfo de su derecho:

- Yo he sido el don Gil fingido/ célebre ya por mis calzas,/temido por alma en pena; / por serlo tú de mi almal dame esa mano.

- Confusol te la beso, prenda caral y agradecido de verlque cesaron por tu causal todas mis persecuciones.

\section{Se restaura el orden perturbado}

Don Pedro, padre de doña Inés, entiende ahora el conjunto de trampas urdidas por doña Juana que le tenían confundido.

Desvanecidas éstas, se vuelven a reconstruir las parejas:

La de doña Inés y don Juan:

- Antes, por ver que ya doña Inés/ me paga finezas, tengo salud. 
- Dueño sois don Juan de mí y mi casa.

A doña Clara que quedaba desparejada, se le encuentra como esposo a su primo:

- Don Antonio lo ha de ser/ de la hermosa doña Clara.

Y el colofón es la boda de don Martín y doña Juana; don Diego reconoce a su yerno, y don Martín no quiere que falte su padre tan culpable de su superado infortunio:

- Ya, don Martín, sois mi hijo.

- Mi padre que venga falta / para celebrar mis bodas.

\section{c. Cuando baja el telón}

Cuando la luz se hace sobre la trama se ve claro que en Don Gil y sus calzas todo lo ha obtenido la agudeza y la constancia de la mujer traicionada, resplandeciendo la justicia lograda con habilidad, astucia e ingenio. ${ }^{76}$

\section{La nota cómica}

La pone Caramanchel que irrumpe con atuendo estrafalario pidiendo oraciones por el alma en pena de su amo, de quien no sabe si es hombre o mujer, porque sigue sin percatarse que todo ha sido un montaje.

Caramanchel concluye ponderando a la mujer, que en este caso ha sido la que con su empeño ha llevado a la solución. Una vez más la mujer tema predilecto de Tirso.

- $Y_{\text {¿sois hombre o sois mujer? }}$

- Mujer soy.

- Esto bastabal para enredar treinta mundos. 
2. Las bodas frente al incumplimiento y la avaricia

Llega finalmente el padre de don Martín, el otro cómplice del desafuero. Don Pedro anuncia la triple boda como restauración del orden justo que reconstruye las confusas parejas.

- Don Martín, agora acaba/ vuestro padre de apearse.

- Vamos, pues, porque se hagan/ las bodas de todos tres.

Tirso, bajo la máscara gozosa de la comedia, devuelve las conductas al orden, como no podía ser menos por su condición. Tirso, que personalmente está lejos de esos conflictos, conociéndolos los disculpa y devuelve a una posesión tranquila. ${ }^{77}$

\section{Con calzas al final de la comedia}

Dos brevísimas intervenciones, dan fin: la de doña Juana que termina su historia con la despedida acostumbrada, y la cómica de Caramanchel el desconcertado pícaro, con la referencia a un suceso que facilitó a Tirso el título de esta Comedia.

- Y porque su historia acaba/ don Gil de las calzas verdes.

- Y su comedia con calzas.

Con esa alusión y con llamar Osorio al criado de don Martín parece recordar Tirso el chistoso y muy reído incidente de habérsele caído las calzas al gracioso Osorio representando un entremés, accidente ocurrido en $1614 .^{78}$

\section{CONCLUSIONES}

1. ${ }^{a}$ Una múltiple crítica social es la lección de esta Comedia, a saber: la opresión de las convenciones sociales, el incumplimiento de la palabra empeñada, el atropello de la libertad de los hijos por la imposición paterna, el interés codicioso, los engaños y falsificación.

2. ${ }^{a}$ El desenlace restaura el derecho y orden justo, con la celebración de la triple boda de unos matrimonios prometidos, realmente queridos y libres de toda imposición paterna.

77 Cfr. Estudios de literatura religiosa española, Madrid, Gredos, 1964.

78 A este incidente alude también Alarcón en Todo es ventura. 
3. ${ }^{\text {a }}$ Se plantea el tema importante de fondo de la comedia, de la libertad de matrimonio de los jóvenes enamorados, frente a los intereses pecuniarios de sus padres ambiciosos. La comedia refleja en esta época la norma progresista que se impone a raíz de la Reforma del Concilio de Trento.

$4{ }^{a}$ Y todo ello unido al triunfo de la mujer que sin dejarse acomplejar, por sí misma, sin necesidad de otra ayuda, puede poner en marcha con su ingenio y tesón la recuperación de su honor. 